\title{
Territorial Dispute between China and Vietnam in the South China Sea: A Chinese Lawyer's Perspective
}

Junwu Pan *

Although China and Vietnam are involved in both territorial and boundary disputes in the South China Sea, at present, managing the territorial dispute over the Spratly Islands is more significant than anything else. Analysis of the dispute based on international law, particularly on the ICJ case law, may help the two sides to manage their dispute in a new perspective and generate political willingness to negotiate the joint development area instead of the sovereignty over the islands. China's policy that the joint development area around the disputed islands is negotiable is quite a positive signal for peace in the South China Sea and provides a practical basis for new negotiations between China and Vietnam.

\section{Keywords}

South China Sea, Spratly Islands, Territorial Dispute, Joint Development, ICJ

\section{Introduction}

The disputes in the South China Sea are extremely complicated. They involve as many

* Associate Professor of the Northwest University of Politics and Law ("NUPL”), Xi' an, China. LL.M.(NUPL), Ph.D. (King's College, London). The author would like to thank Professor Rein M?llerson for supervising his research work. This article is a part of the research project of "Reconstructing China's New Mechanism to Settle the Disputes in the South China Sea," supported by the Academic Research Foundation for returning overseas students(教外司留 [2011] No. 1568). The author may be contacted at junwupan@yahoo.com/Address: Mail Box 101, Northwest University of Politics and Law, No.300 South Chang' an Road, Xi' an, 710063 P. R. China. 
as six parties, namely, mainland China, Taiwan, Malaysia, Vietnam, the Philippines and Brunei. They make claims either in whole or in part to the small islets and their surrounding water areas. Each of them is unswervingly strengthening its claims due to the prospect of rich oil and gas deposits around the islands and the strategic location of the area. The disputes between China and Vietnam in this area are regarded as the most critical source of potential conflict. The two nations have been vigorous in claiming sovereignty over all features in the Spratly Islands and Paracel Islands; both were drawn into military conflicts in 1974 and 1988. In 2010, when Vietnam signaled its willingness to allow U.S. involvement, China immediately responded by declaring that the South China Sea is part of its 'core interests.' 1 It indicates that Chinese interest in this area should be protected at all cost. However, China and Vietnam are still trying to seek measures to avoid future military conflict.

There are two major disputes existing in the South China Sea between China and Vietnam: the dispute over the sovereignty of the islands and the maritime delimitation. Unless the fundamental and intractable disagreements on sovereignty over the islands can be resolved, it will not be possible to negotiate any boundary agreements in areas of the South China Sea. At present, attention is highly concentrated on the territorial dispute between China and Vietnam over the Spratly Islands because of its high risk of war. The dispute over sovereignty is governed by customary international law on the acquisition of territory as articulated by international courts and tribunals in cases concerning sovereignty disputes. If the political will can be generated to use international law, particularly the case law of the International Court of Justice ("ICJ") to justify their claims and manage the dispute, there would be a window of opportunity to pursue progress.

The main objective of writing this paper is to propose the way for the peaceful resolution of disputes in the South China Sea from a Chinese lawyer's perspective. This paper is composed of five parts including Introduction and Conclusion. Part II will examine the different versions of sovereignty disputes over the islands on the South China Sea. In this paper, the author will compare the positions of both China and Vietnam based on the historical and positive evidences. Part III will analyze the cases of international courts regarding maritime territorial disputes and applies them to the

1 When U.S. Secretary of State Hillary Clinton said on July 23, 2010 in Hanoi that she aligned the United States firmly with South East Asia's approach to overlapping claims in the South China Sea. In response, China immediately described the South China Sea as a 'core interest,' complaining 'encirclement' and criticizing unwarranted interference by the US in matters that do not concern it. See Vaudine England, Why are South China Sea tensions rising?, BBC NEWS (Sept. 3, 2010), available at http://www.bbc.co.uk/news/world-asia-pacific-11152948 (last visited on Jan. 31, 2012). See also Toshi Yoshihara \& James Holmes, Can China Defend a 'Core Interest' in the South China Sea?, 34 The Washington Q. 46 (2011). 
current dispute between the two countries. Part IV will propose ways to resolve the disputes and manage a joint development area in the future.

\section{Different Positions on Sovereignty Claims}

\section{A. Chinese Position 2}

China claims that it first discovered the Spratly (called Nan Sha in the Chinese language) Islands more than 2,000 years ago. Chinese historical books and documents, such as $Y i$ Zhou Shu (Scattered Books of the Zhou Dynasty), Shi Jing (The Classics of Poems), Zuo Zhuan (Zuo's Commentaries) and Guo Yu (Statements of the States), contain the relevant records. ${ }^{3}$ The Chinese authoritative patrol through the Spratly Islands can be dated back to the Han Dynasty (206 B.C. - 220 A.D.). 4 This practice in the name of the Chinese government continued until modern times. 5 The historical books describing the seven large-scale voyages through the South China Sea led by the well-known Chinese navigator Zheng He (also known as Cheng Ho) under the order of the Ming imperial court between 1405 and 1433 recorded the location of the Spratly Islands. 6

In 1909, Zhang Renjun as Governor of Guangdong and Guangxi Province sent Li Zhun, the naval officer-in-charge, to the Spratly Islands area. His crew erected stone markers, raised Chinese flags, and held cannon-shooting ceremonies to demonstrate China's sovereignty.7 In 1911, when the Republic of China ("ROC") replaced the Qing Dynasty, the Chinese government entrusted administration of the Spratly Islands to the local government of Hainan, which was a special prefecture within Guangdong Province. ${ }^{8}$ Later, when France and Japan occupied the Spratly Islands, the Chinese government protested and emphasized that neither the French nor the Japanese occupations changed the territorial status of the islands in the South China Sea because they were illegal and invalid under international law. ${ }^{9}$

2 Junwu Pan, Toward a New Framework for Peaceful Settlement of China's Territorial and Boundary Disputes 168 (2009).

3 These books are the classic collections of the "Spring and Autumn" Period (770-476 B.C.). See Jianmin Shen, China's Sovereignty over the South China Sea Islands: A Historical Perspective, 1 ChINESE J. INT' L L. 101-105 (2002).

$4 \quad$ Id.

$5 \quad$ Id. at $112-115$.

$6 \quad$ Id. at 112 .

7 MuZheng Duan, International LaW 156 (1989).

8 Jianmin Shen, International Law Rules and Historical Evidences Supporting China's Title to the South China Sea Islands, 21 HaStings INT' L \& ComP. L. Rev. 37 (1997-1998).

9 Id. at $42-44$. 
At the end of World War II, Japan renounced the Spratly Islands and withdrew its troops. In November 1946, the ROC sent representatives with warships to resume its control over the islands and set up administration to exercise jurisdiction over the islands in the South China Sea including the Spratly Islands under the Guangdong Province and later the Hainan Administrative District. 10 In 1956, the ROC under the name of China sent its naval contingent to the Spratly Islands to defend the Filipino invasion and retained its troops on the Taiping Island up to now. ${ }^{11}$

The People's Republic of China ("PRC"), which was founded in October 1949, has never given up its claims to the Spratly Islands. The transition of government in China has not interrupted China's sovereignty over the Spratly Islands.12 On September 4, 1958, the PRC promulgated a decree in which it confirmed its sovereignty over the Spratly Islands.13 In March 1959, the PRC established an office in charge of the Spratly Islands and other islands in the South China Sea. The office during the Cultural Revolution (1966-1976) changed its name to the Revolutionary Committee of the Xisha (Paracel), Zhongsha (Macclesfield) and Nansha (Spratly) Islands of Guangdong Province.14 In January 1988, the PRC sent its troops to some islands of the Spratly archipelago and built a ferry and a helicopter airport on Yong Shu Island (Fiery Cross or N. W. Investigator Reef). The PRC also built a Maritime Observation Station on the Island based on the UNESCO plan and support. In March 1988, the PRC even fought against an invasion of the Spratly Islands by Vietnam. 15 China claims that its jurisdiction over the Spratly Islands has been consistent and the occupations of parts of the Spratly Islands by foreign countries are all illegal and invalid.16

The maps published by the Qing Dynasty of China (1644-1912) constitute the evidence to support the above claims by China. These maps include: the 1724 Map of

10 Teh-Kuang Chang, China's Claim of Sovereignty over Spratly and Paracel Islands: A Historical and Legal Perspective, 23 CASE W. RES. J. INT'L L. 412 (1991).

11 Martin Katchen, The Spratly Islands and the Law of the Sea: "Dangerous Ground" for Asian Peace, 17 Asian SuRV. 1179 (1977).

12 Chang, supra note 10 , at 408.

13 Article 2 of the Declaration of Territorial Sea of the PRC (available only in Chinese), available at http://news.xinhuanet.com/ziliao/2003-01/24/content_705061.htm (last visited on Jan. 31, 2012).

14 See Memorandum of the Ministry of Foreign Affairs of the People's Republic of China on the Question of Xisha and Nansha Islands, Renmin Ribao(人民日報), May 12, 1988, available at http://wuxizazhi.cnki.net/Search/ GWYB198812003.html (last visited on April 28, 2012).

15 Chang, supra note 10 , at 408.

16 Dizu Shi, Nanhai zhudao zigu jiushi woguo lingtu (The Islands in South China Sea have been China's Territory ever since Anciant Times), Guang Ming Daily (Nov. 24, 1975). See also the Chinese Government's Statements, People's DaILY (Jul. 17, 1971; Jan. 12, 1974; Jan.20, 1974; Feb.5, 1974; Dec.29, 1978; Sept. 27, 1979; Jan. 30, 1980; Jul. 22, 1980; Nov. 2, 1982; Jan. 8, 1986; Dec. 3, 1987; Apr. 21, 1988; Sept. 29, 1989; Dec. 28, 1990; Jan. 24, 1992; Sept. 9, 1994; Dec. 16, 1994). 
Administrative Divisions of the Whole China; Map of Provinces of the Qing Dynasty; the 1755 Map of Administrative Divisions of the Whole China; Map of Provinces of the Imperial Qing Dynasty; the 1767 Map of Unified China of the Great Qing for Ten Thousand Years; the 1810 Topographical Map of Unified China of the Great Qing for Ten Thousand Years; and the 1817 Map of Unified China of the Great Qing for Ten Thousand Years. 17 (Map 1)

\section{Map 1: The 1817 Map of Unified China of the Great Qing for Ten Thousand Years (The Part of South China Sea)}

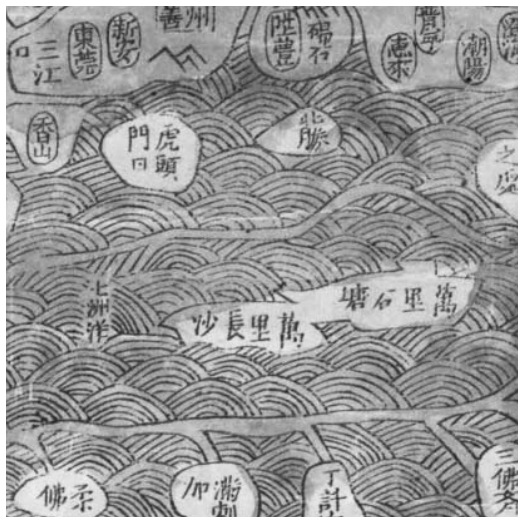

Source: American Geographic Society Library, Digital Map Collections, available at http://collections.lib.uwm.edu/cdm4/item_viewer.php?CISOROOT=/agdm\&CISOPTR=753 (last visited on Mar. 1, 2012)

The maps published in other countries also serve as proof of international recognition of the Spratly Islands as China's territory, which even include the Vietnamese official World Atlas that was published by the Surveying and Mapping Bureau of the Prime Minister's Office of Vietnam in 1972.18 (Map 2)

17 Ministry of Foreign Affairs of the People's Republic of China, International Recognition of China's Sovereignty over the Nansha Islands, available at http://www.fmprc.gov.cn/eng/topics/3754/t19232.htm (last visited on Jan. 31, 2012).

18 The following maps are mentioned by the Chinese Government: (1) The Welt-Atlas published by the Federal Republic of Germany in 1954, 1961 and 1970, respectively; (2) World Atlas published by the Soviet Union in 1954 and 1967, respectively; (3) World Atlas published by Romania in 1957; (4) Oxford Australian Atlas and Philips Record Atlas published by Britain in 1957 and Encyclopedia Britannica World Atlas published by Britain in 1958; (5) World Atlas drawn and printed by the mapping unit of the Headquarters of the General Staff of the People's Army of Vietnam in 1960; (6) Haack Welt Atlas published by German Democratic in 1968; (7) Daily Telegraph World Atlas published by Britain in 1968; (8) Atlas International Larousse published by France in 1968 and 1969, respectively; (9) World Map Ordinary published by the Institut Geographique National ("IGN") of France in 1968; (10) World Atlas published by 
Map 2: the Vietnamese official World Atlas that was published by the Surveying and Mapping Bureau of the Prime Minister's Office of Vietnam in 1972

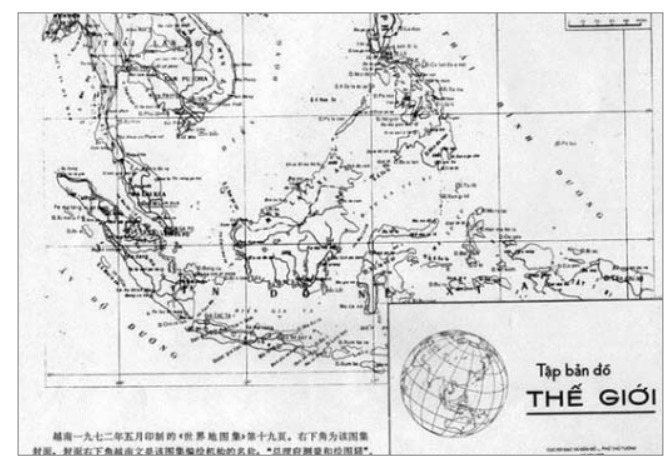

Source: National Library of China

In addition, all the maps published by both the ROC and the PRC included the Spratly Islands as Chinese territory. ${ }^{19}$ In 1948, the ROC officially published the Atlas of Administrative Area of the ROC. This map has had substantial influence over subsequent maps published by either the mainland China or Taiwan.20 The maps of the South China Sea published by the PRC were the same as before 1949.21

China believes that its sovereignty over the Spratly Islands has been recognized at the international level. In 1955, in Manila, the International Civil Aviation Organization ("ICAO") held the Conference on Pacific Region Aviation ( hereinafter the Conference), which was attended by the representatives from sixteen countries and areas, such as Vietnam, Australia, Canada, the U.K., the U.S., Japan, France, Thailand, New Zealand, the Philippines, the ROC, etc. When the ICAO at the Conference assigned the ROC the task to improve meteorological observations throughout the Spratly Islands, no representatives, even including the ones from Vietnam, made a protest or reservation.22

The Vietnamese government acknowledged China's sovereignty over the Spratly Islands. When China published new names for each of the Islands in 1947, neither Vietnam nor any other country protested China's actions. 23 On June 15, 1956,

\footnotetext{
the Surveying and Mapping Bureau of the Prime Minister's Office of Vietnam in 1972; and (11) China Atlas published by Neibonsya of Japan in 1973. Id.

19 Shen, supra note 8 , at 37.

20 Keyuan Zou, The Chinese Traditional Maritime Boundary Line in the South China Sea and Its Legal Consequences for the Resolution of the Dispute over the Spratly Islands, 14 InT' L J. MAR. \& COASTAL L. 33 (1999).

22 Ministry of Foreign Affairs of the People's Republic of China, supra note 17.

23 Jinming Li \& Dexia Li, The Dotted Line on the Chinese Map of the South China Sea: A Note, 34 OcEan Dev. \& INT'L
}

21 Id. at 34. 
Vietnamese Vice Foreign Minister Ung Van Khiem publicly stated to the Chinese Charge d'Affaires, Li Zhimin that: "According to Vietnamese data, the Xisha (Paracel) and Nansha (Spratly) Islands are historically part of Chinese territory." 24 On September 4, 1958, China proclaimed the breadth of its territorial sea to be 12 nautical mile ("nm") and specified that this provision applies to all Chinese territories including the Spratly Islands. 25 On September 14, Vietnam's late premier Pham Van Dong in his note to Beijing affirmed that Vietnam "recognizes and supports" China's declaration and "respects this decision." 26 China believes that these recognitions constitute estoppel and thus Vietnam is estopped from asserting otherwise. 27

From China's viewpoint, international treaties also support its claims. The Spratly Islands should be part of the Chinese territory which Japan seized during World War II and therefore should be returned to China after the war under both the 1943 Cairo Declaration and the 1945 Potsdam Proclamation.28 A number of events have made it clear that these islands are China's territory. In 1946, China held a take-over ceremony on the Spratly Islands. Later, in 1952, the year when the San Francisco Treaty went into force, Japan stated that it had renounced all rights to Taiwan, the Spratly Islands, and other islands that it occupied during the war. ${ }^{29}$ In the same year, the $15^{\text {th }}$ map of

L. 290 (2003). See also The Issue of South China Sea, Ministry of Foreign Affairs People's Republic of China June 2000, available at http://www.fas.org/news/china/2000/china-000600.htm (last visited on Mar. 21, 2012).

25 Han Zhenhua, Woguo nanhai zhudao shiliao huibian (The Compilation of Historic Materials on the South China Sea Islands) 445 (1988).

26 Han, supra note 24 .

27 Id.

28 In 1943, China, the United States and the United Kingdom announced in the Cairo Declaration: "It is their purpose that Japan shall be stripped of all the islands in the Pacific which she has seized or occupied since the beginning of the First World War in 1914, and that all the territories Japan has stolen from the Chinese, such as Manchuria, Formosa, and the Pescadores, shall be restored to the Republic of China." The 1945 Potsdam Proclamation stated: "The terms of the Cairo declaration shall be carried out and Japanese sovereignty shall be limited to the islands of Honshu, Hokkaido, Kyushu, Shikoku and such minor islands as we determine." The Chinese Government interpreted it as follows: "During World War II, Japan invaded and occupied China's Nansha Islands. China made unremitting efforts for the recovery of these islands from the Japanese occupation. In 1943, China, the United States and the United Kingdom announced in the Cairo Declaration that all the territories that Japan had stolen from China should be "restored to China," including "Manchuria, Taiwan and the Penghu Islands." At that time, Japan put the Nansha Islands under the jurisdiction of Taiwan. The territories to be restored to China as identified in the Cairo Declaration naturally included the Nansha Islands. The 1945 Potsdam Proclamation confirmed once again that the stolen territories should be restored to China. According to the Cairo Declaration and Potsdam Proclamation, China recovered the Nansha Island in 1946." Han, supra note 24. See also Ministry of Foreign Affairs People's Republic of China, The Issue of South China Sea (June 2000), available at http://www.fas.org/news/china/2000/ china-000600.htm (last visited on Mar. 21, 2012).

29 Id. Here, the PRC actually refers to the the 1951 Treaty of Peace with Japan and the 1952 Treaty of Peace between the Republic of China and Japan, in which Japan denounced its right to the Spratly Islands, though it once refused the binding force of the two treaties upon itself due to its absence in the signatories. 
Southeast Asia of the Standard World Atlas, recommended by the signature of the then Japanese Foreign Minister, Katsuo Okazaki, marks as part of China all the Paracel and Spratly islands which Japan had to renounce as stipulated in the Treaty of Peace with Japan. 30 (Map 3)

Map 3: The 15th Map of Southeast Asia included in the Standard World Atlas (1952), recommended by the then Japanese Foreign Minister, Katsuo Okazaki.

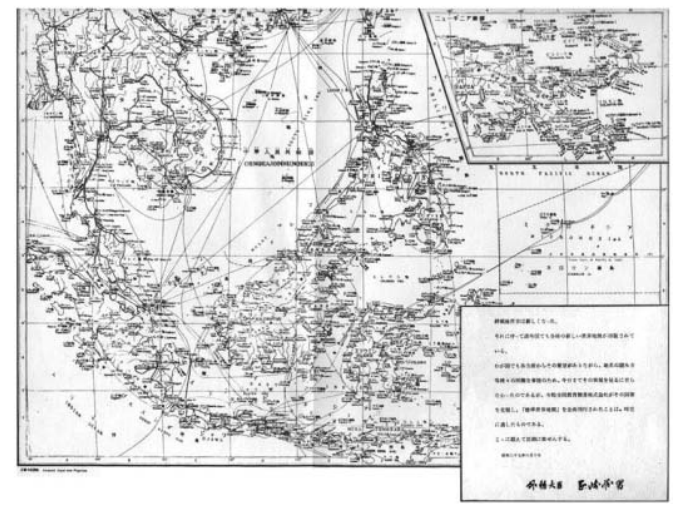

Source: National Library of China

The PRC has reiterated its sovereignty over the Spratly Islands. In 1951, the PRC Foreign Minister reconfirmed China's sovereignty over the Spratly Islands in his statement. ${ }^{31}$ In 1956, the PRC Foreign Ministry pronounced a similar statement. 32 In 1958, the PRC issued a Declaration of the Territorial Sea, which claimed that the Spratly Islands belonged to China. 33 In the following years, such announcements continued. ${ }^{34}$ On February 25, 1992, the Chinese National People's Congress, which functions as the Parliament of the PRC, codified China's claim to sovereignty over the Spratly Islands by passing the Law of the PRC on the Territorial Sea and Contiguous Zone. Article 2 of the

31 In 1951, before the Treaty of Peace with Japan, Zhou En-lai, the PRC Foreign Minister, stated: "These lands ... although they were occupied by Japan for some time during the war ... were all taken over by the Chinese government following Japan's surrender. Whether or not the U.S.-British Draft Treaty contains provisions on this subject, and no matter how these provisions are worded, the inviolate sovereignty of the PRC over [Spratly] Islands ... will not be affected in any way." See Brinton Scott, Resolving the Question of Sovereignty over the Spratly Islands, 3 WillameTte Bull. INT'L L. \& POL'y 44 (1995).

32 Hsun-Cheng Shao, Chinese Islands in the South China Sea, 13 People's CHINA 27 (1956).

33 L. G. Gordner, The Spratly Island Dispute and the Law of the Sea, 25 OcEAN DEv. \& InT' L L. 64 (1994).

34 Shi, supra note 16. 
Law provides that China's territory includes the Spratly Islands. 35 In sum, China claims all the islands in the Spratly archipelago based on discovery and occupation, treaty and estoppel.

\section{B. Vietnamese Position}

Vietnam has claimed that long ago the Vietnamese people discovered the archipelagoes of Spratly (called Truong Sa in Vietnamese); the Vietnamese state has occupied and exercised its sovereignty over them ever since. Ancient Vietnamese geographical books and maps record clearly that Spratly Islands had long since been a Vietnamese territory. 36

As the sovereign, the Vietnamese feudal state in past centuries conducted many geographical and resources surveys of the archipelagoes of Spratly. The results of those surveys have been recorded in Vietnamese literature on geography and history published since the 18th century. Noticeable examples are as follows: Phu Bien Tap Luc (1776); Dai Nam Thuc Luc Tien Bien (1844), a book on the history of the Nguyen Lords completed by the National Institute of History under the Nguyen dynasty in 1884; Dai Nam Nhat Thong Chi (1882); Lien Trieu Hien Chuong Loai Chi (1821); Hoang Viet Dia Du Chi (1833); Viet Su Cuong Giam Khao Luoc (1876); and Dai Nam Thuc Luc Tien Bien (1844).37

The Nguyen Emperors did their best to consolidate Vietnam's sovereignty over the archipelagoes of Spratly from their coming to power in 1802 until the signing of the 1884 Treaty with France. 38

Dai Nam Thuc Luc Chinh Bien (1848) describes some of the measures taken by the Nguyen Emperors to consolidate Vietnam's sovereignty over the Spratly Islands. Based on the ancient Vietnamese works of history and geography and the testimonies of western navigators and missionaries, the conclusion was made that the Vietnamese State from one dynasty to another over hundreds of years had continuously exercised its sovereignty over the archipelago of Spratly. 39

Vietnam also invokes the principle of State succession to strengthen its claim. South

Article 2 of the Law of the PRC on the Territorial Sea and Contiguous Zone provides: "The PRC's territorial waters refer to the island waters contiguous to its territorial land. The PRC's territorial land includes the mainland and its offshore islands, Taiwan, and the various affiliated islands, including Diaoyu Dao (Senkaku Islands), the Penghu Islands (Pescadores), the Nansha Islands (Spratly), and other islands that belong to the PRC.” See L. Wang \& P. H. Hearse, The New Legal Regime for China's Territorial Sea, 25 OCEAn Dev. \& INT' L L. 431-442 (1994).

36 See The Hoang Sa and Truong Sa Archipelagos: Vietnamese Territories, Ministry of Foreign Affairs Socialist Republic of Vietnam 8 (1981), available at http://hoangsa.org/tailieu/Bo_ngoai_giaoVietnam81.pdf (last visited on Jan. 31, 2012).

37 Id. at 9-12.

38 Id. at 13.

39 Id. 
Vietnam once viewed its title to the islands as succession from its French colonial power. 40 After the 1884 Treaty was signed with the Nguyen dynasty, France represented Vietnam's interests in foreign affairs and was bound to protect Vietnam's sovereignty and territorial integrity. In the framework of such overall commitment, France carried on the exercise of Vietnamese sovereignty over the Spratly Islands. On July 24, 1933, France informed Japan of French troops stationing on the major islands in the Spratly archipelago. Japanese then presented a protest, but the French authorities rejected it. 41

On July 7, 1951, Tran Van Huu, head of the Bao Dai Government's delegation to the San Francisco Conference on the peace treaty with Japan declared that the archipelagoes of Spratly had long been part of Vietnamese territory. He said that: "As we must frankly profit from all the opportunities offered to us to stifle the germs of discord, we affirm our rights to the Spratly Islands and Paracel Islands, which have always belonged to Vietnam." The declaration met with no challenge or reservation from any representative of the fifty-one nations at the Conference. 42

On October 22, 1956, the Saigon administration annexed the Spratly archipelago to Phuoc Tuy province. Between 1961 and 1963, the Saigon administration installed sovereignty markers on the major islands of the Spratly archipelago, viz Truong $S a, A n$ Bang, Song Tu Tay, Song Tu Dong, Thi Tu and Loai Ta. In July 1973, the Institute of Agricultural Surveys under the Ministry of Agricultural and Land Development of the Saigon administration conducted a survey on Nam Ai Island (Nam Yit) in the Spratly archipelago. 43

On September 6, 1973, the Saigon administration annexed the Spratly Islands, including An Bang, Itu Aba, Song Tu Dong, Song Tu Tay, Loai Ta and Thi Tu, Nam Ai and Sinh Ton and other adjacent islands to Phuoc Hai village, Dat Do district, Phuoc Tuy province. Feeling keenly about Vietnam's age-old sovereignty over the Spratly Islands, the successive administrations of South Vietnam never failed to defend it whenever a foreign country attempted to dispute it or occupied any part of the Spratly Islands. 44 On June 1, 1956, the Foreign Ministry of the Saigon administration issued a statement reaffirming Vietnam's sovereignty over the Spratly Islands as the People's Republic of China, Taiwan and the Philippines each claimed that the archipelago belonged to them. 45 After the reunification of Vietnam in 1976, the Government of the Socialist

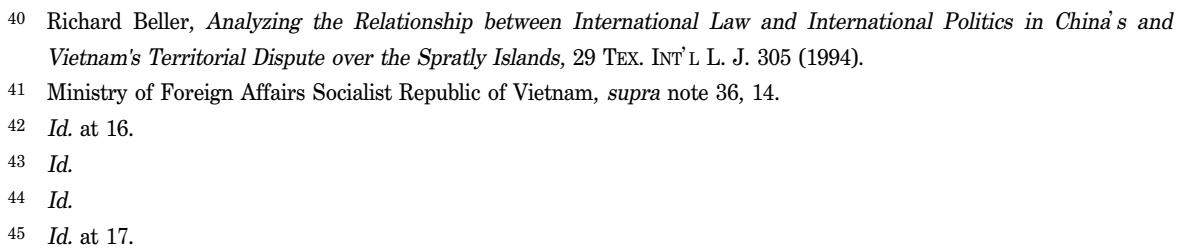


Republic of Vietnam reaffirmed on various occasions Vietnam's sovereignty over the Spratly Islands.46 In short, Vietnam claims ownership of the entire Spratly Islands mainly based on discovery and occupation. 47

\section{The ICJ Case Law and Its Application}

The ICJ case of Sovereignty over Pulau Ligitan and Pulau Sipadan between Indonesia and Malaysia (hereinafter the Indonesia v. Malaysia Case), 48 in which the two Southeast Asian nations are involved, also includes competing for the sovereignty of very small uninhabited islands. As the dispute was also caused by the exploitation of potential oil resources around the disputed islands, it embodies many legal implications for the territorial disputes in the South China Sea.

\section{A. Legal Implications contained in the Indonesia v. Malaysia Case}

\section{Overview}

Ligitan and Sipadan are two very small islands located in the Celebes Sea, off the northeast coast of the island of Borneo. After their independence, Indonesia and Malaysia began to grant oil-prospecting licences in waters off the east coast of Borneo during the 1960s. The present dispute crystallized in 1969 in the context of discussions concerning the delimitation of the respective continental shelves of the two States. Following those negotiations a delimitation agreement was reached on October 27, 1969. It entered into force on November 7, 1969. However, the agreement did not cover the area around the islands of Ligitan and Sipadan. 49 In 1998, Indonesia and Malaysia, by special agreement, asked the ICJ to determine sovereignty of the two originally uninhabited islands of Ligitan and Sipadan.

\section{Treaty Law}

In the beginning, ICJ recalled the complex historical background of the dispute between the parties.50 Then, it examined the titles invoked by them. Indonesia's claim to sovereignty over the islands was based primarily on a title stemming from the 1891

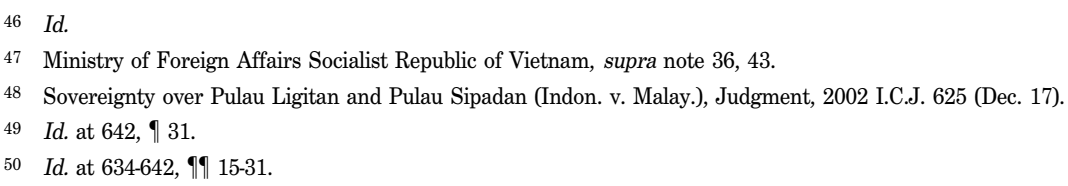


Convention between Great Britain and the Netherlands. Indonesia maintained that: "Under the Convention title to those islands vested in the Netherlands, and now vests in Indonesia." 51 Malaysia, for its part, asserted that the 1891 Convention just clarified the boundary of land on the islands of Borneo and Sebatik, different from the islands of Ligitan and Sipadan. 52

The ICJ then directly examined the 1891 Convention, the relevant travaux préparatoires, the subsequent conduct of the parties to the Convention and the cartographic material submitted by the parties. Eventually, the ICJ concluded that the Convention did not constitute a title on which Indonesia can found its claim to Ligitan and Sipadan. 53

\section{Uti possidetis}

The ICJ turned to the question whether Indonesia or Malaysia obtained title to Ligitan and Sipadan by succession. 54 The Court did not accept Indonesia's contention that it retained title to the islands as successor to the Netherlands, which allegedly acquired it through contracts concluded with the Sultan of Bulungan, the original title-holder. Nor did the ICJ accept Malaysia's contention that it acquired sovereignty over the islands of Ligitan and Sipadan further to a series of alleged transfers of the title originally held by the former sovereign, the Sultan of Sulu, that title having allegedly passed in turn to Spain, the United States, Great Britain on behalf of the State of North Borneo, the United Kingdom of Great Britain and Northern Ireland and finally to Malaysia. 55

\section{Effective Control}

Having found that neither of the parties had a treaty-based title to Ligitan and Sipadan, the ICJ next considered the question whether Indonesia or Malaysia could hold title to the disputed islands by virtue of the effectivités cited by them. ${ }^{56}$ In this regard, the Court relied on activities evidencing an actual, continued exercise of authority over the islands, i.e., the intention and will to act as sovereign to determine whether the parties had gained the sovereignty of the two islands.

Indonesia believed that it had obtained effective control of the disputed islands based on the traditional activities by Indonesian fishermen around the islands. The ICJ refused this claim. The ICJ considered that "activities by private persons cannot be seen

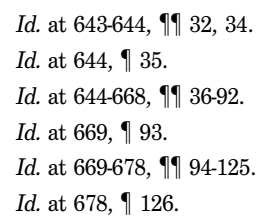


as effectivités if they do not take place on the basis of official regulations or under governmental authority." 57

Malaysia cited the measures taken by the North Borneo authorities to regulate and control the collecting of turtle eggs on Ligitan and Sipadan. It relied on the Turtle Preservation Ordinance of 1917 and maintained that the Ordinance "was applied until the 1950s at least" in the area of the two disputed islands. It further invoked the fact that the colonial authorities of North Borneo constructed a lighthouse on Sipadan in 1962 and another on Ligitan in 1963; those lighthouses, existing even today, have been maintained by the Malaysian authorities since its independence.58 The ICJ noted that:

The activities relied upon by Malaysia are "modest in number" but they are diverse in character and include legislative, administrative and quasi-judicial acts. They cover a considerable period of time and show a pattern revealing an intention to exercise State functions in respect of the two islands in the context of the administration of a wider range of islands. 59

The ICJ further stated: "At the time when these activities were carried out, neither Indonesia nor its predecessor, the Netherlands, ever expressed its disagreement or protest." 60

On December 17, 2002, the ICJ, in its judgment, concluded that: "Malaysia has title to Ligitan and Sipadan on the basis of effectivités." 61 So the first question concerning the dispute over the sovereignty of the Spratly Islands is whether there have been valid treaties to decide the sovereignty of the Spratly Islands. If there are no valid treaties, the next question is whether uti possidetis and effective control can be applied to determine who has stronger legal basis to claim the Spratly Islands.

\section{B. Appraisal of the Case of Spratly Sovereignty}

\section{Treaty}

On June 26, 1887, China and France signed a convention that included the territory division line between China and Vietnam that was then a French Protectorate. 62 The

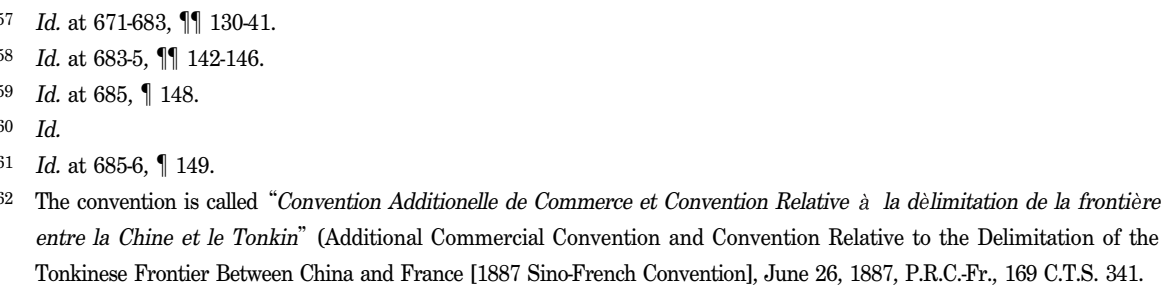
entre la Chine et le Tonkin" (Additional Commercial Convention and Convention Relative to the Delimitation of the Tonkinese Frontier Between China and France [1887 Sino-French Convention], June 26, 1887, P.R.C.Fr., 169 C.T.S. 341. 
convention provided that: "The French laid claim to territory west of the $105^{\circ} 43^{\prime}$ east of Paris, therefore ceding territory east of this line to China." 63 In 1933 when the French foreign Ministry announced that it had occupied some of the Spratly Islands, China protested against the French action and invoked the 1887 Sino-French Convention. China interpreted that the convention covered the Spratly Islands which were far east of the line and thus it was China's territory. ${ }^{64}$ France responded that the Treaty only applied to the Mancay area in northern Vietnam.65

Ironically, in the 1980s, when Vietnam issued a statement on November 12, 1987 claiming that the 1887 Sino-French Convention also set the maritime boundary line between Vietnam and China, the PRC immediately protested about the Vietnamese statement, denying that boundary delimitation was set in the 1887 Convention between China and France.66 In the 1990s, China and Vietnam negotiated to resolve the maritime boundary dispute in the Gulf of Tonkin (Beibu Gulf in Chinese/Bac Bo Gulf in Vietnamese). At first, the two parties found themselves far apart on the issue of validity of the 1887 Convention in the maritime delimitation. On December 25, 2000, China and Vietnam finally agreed that the 1887 Convention did not set the maritime boundary between them and officially signed an Agreement on Fishery Cooperation in the Gulf of Tonkin together with the Agreement on Maritime Boundary Delimitation in the Gulf of Tonkin. 67 Thus, a conclusion can be drawn that the 1887 Convention did not cover the Spratly Islands.

Other treaties relating to the Spratly Islands dispute as follows: the 1943 Cairo Declaration; the 1945 Potsdam Proclamation; the 1951 Treaty of Peace with Japan; and the 1952 Treaty of Peace between the Republic of China and Japan. As far as these treaties are concerned, the key issue is to decide whether the Spratly Islands fall into the Chinese territory Japan had seized from China under the Cairo Declaration and the Potsdam Proclamation. At this point, China has the burden of proof if it depends on the above two declarative measures to claim the Spratly Islands. Although the Treaty of Peace with Japan and the Treaty of Peace between the ROC and Japan provided that Japan renounced the Spratly Islands, the treaties themselves contained no words mentioning to whom Japan renounced the Spratly Islands. In addition, the two treaties can only be used as evidence instead of valid treaties because the PRC refused to accept

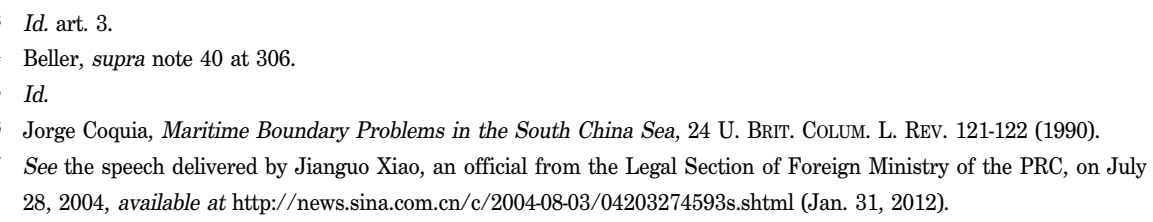


them. Does the statement that Japan renounced the Spratly Islands in the Treaty of Peace between the ROC and Japan suffice to support the claim that Japan renounced them to China? It needs further evidence to support it. It seems that the fifteenth map of Southeast Asia included in the Standard World Atlas, recommended by the then Japanese Foreign Minister, Katsuo Okazaki and just issued in the second year after the peace conference in San Francisco, is a quite convincing piece of evidence to support the explanation that the Spratly Islands fall into the Chinese territory seized by Japan and later renounced to China because the map clearly marks the Spratly Islands as the Chinese territory.

\section{Uti possidetis}

Vietnam cannot obtain the title to Spratly Islands by succession from France because France has never gotten the sovereignty over the Islands at all. In July 1933, when France, the then protector of Vietnam, occupied nine small islands of the Spratly Islands, China responded by strong protest.68 On March 22, 1977, Gerard Chesnel, the French Consulate in Hong Kong, clearly stated that the agreement signed by France in Geneva in 1954 recognizing the independence of Vietnam does not mention the Spratly Islands as Vietnam's territory at all.69

\section{Effectivités}

Before addressing the issue of effective control, the prerequisite is to decide what time is the 'critical date' before which the parties were able to show the consolidation of their title or their fulfilment of the requirement of the doctrine of occupation. ${ }^{70}$ In the Indonesia v. Malaysia Case, the ICJ considered the year of 1969 as the critical date because the delimitation of the respective continental shelves was negotiated, and an agreement was reached between the two countries in that year. Although the Parties did not cover the area lying to the east of Borneo in the agreement, they asserted conflicting claims to Ligitan and Sipadan.71 The ICJ further observed that it could not take into consideration acts having taken place after the date on which the dispute between the Parties crystallized unless such acts are a normal continuation of prior acts and are not undertaken for the purpose of improving the legal position of a party which relies on them. ${ }^{72}$

\footnotetext{
68 Zou, supra note 20 , at 32 .

69 Zhenhua Han, Zhongguo Nanhai Zhudao Shiliao Huibian (Historic Archive of China's Xisha and Nansha Islands) 542 (1988).

70 Louis Goldie, The Critical Date, 12 InT' L \& ComP. L. Q. 1251 (1963).

71 Supra note 48 , at 642 , 931.

72 Id. at 682, ๆ 135 .
} 
On December 25, 2000, China and Vietnam, agreeing that the 1887 Convention did not set their maritime boundary, signed an agreement on maritime boundary delimitation in the Gulf of Tonkin. Although China and Vietnam did not cover the Spratly Islands in their agreement, in the context of discussions concerning the delimitation in the Gulf of Tonkin, the dispute over the Spratly Islands crystallized. Thus, the critical date in the case of the dispute over the sovereignty of the Spratly Islands should be the year of 2000; the acts undertaken by any party after 2000 for the purpose of improving its legal position should not be taken into consideration. For example, Vietnam's building of a small airport on the disputed island of Big Spratly with the purpose of sending small groups of Vietnam tourists to the South China Sea in May 2004 should be completely ignored.

In the Indonesia v. Malaysia Case, the ICJ reconfirmed the statement by the Permanent Court of International Justice ("PCIJ") in the Legal Status of Eastern Greenland Case (Denmark $v$. Norway) about the basic elements in an effective control. The statement contains that if claims to sovereignty are not based upon some particular act or title such as a treaty of cession but merely upon continued display of authority, two elements are involved: (1) the intention and will to act as sovereign; and (2) some actual exercise or display of such authority.73

In the Indonesia v. Malaysia Case, the ICJ evaluated that maps in general constitute extrinsic evidence and may be used to establish or reconstitute the real facts along with other evidence of a circumstantial kind.74 A similar evaluation was found in the Eritrea/Yemen Arbitration Case. With respect to the plethora of maps, the Tribunal of the Eritrea/Yemen Arbitration Case was of the opinion that the maps suggested a certain widespread understanding that the islands appertained to Yemen. ${ }^{75}$ The maps displaying the Spratly Islands as Chinese territory, along with the declarations by the different Chinese governments, at least suffice to show China's willingness to control the Spratly Islands. The question is whether it has displayed its authority over the islands in some other effective ways.

Both Chinese and Vietnamese historical books and records, mentioning the Spratly Islands and their early naval patrols in the Spratly Islands, can only be used as evidence to display their effective control. The ICJ observed in the Indonesia v. Malaysia Case that

73 Legal Status of Eastern Greenland Case (Den. v. Nor.), 1933 P.C.I.J. (ser. A/B) No. 53 (Apr. 5), available at http://www.worldcourts.com/pcij/eng/decisions/1933.04.05_greenland.htm (Jan. 31, 2012).

74 The Indonesia v. Malaysia Case, supra note 48, at 667, \ 88; The Frontier Dispute Case (Burk. Faso v. Mali), 1986 I.C.J. 582, ๆ 54 (Dec. 22); The Kasikili/Sedudu Island case (Bots. v. Namib.), 1999 I.C.J. 1098, ๆ 84. (Dec. 13).

75 See Eritrea/Yemen Arbitration Award (1998), ๆ 490, available at http://www.pca-cpa.org (Jan. 31, 2012). See also Barbara Kwiatkowska, The Eritrea/Yemen Arbitration: Landmark Progress in the Acquisition of Territorial Sovereignty and Equitable Maritime Boundary Delimitation, 32 OCEAN DEv. \& INT' L L. 18 (2001). 
it could only consider those acts as constituting a relevant display of authority which leave no doubt as to their specific reference to the islands in dispute as such.76 The ICJ further stated:

Regulations or administrative acts of a general nature could therefore be taken as effectivités with regard to Ligitan and Sipadan only if it was clear from their terms or their effects that they pertained to these two islands. 77

It is a big question whether the Chinese and Vietnamese historical books and records and the early naval patrols undoubtedly constitute a relevant display of authority in the Spratly Islands. Both sides need more substantial evidence to support their claims.

The Chinese and Vietnamese fishermen's use of the islands hardly strengthens their display of authority. In the Indonesia v. Malaysia Case, when Indonesia stated that the waters around Ligitan and Sipadan had traditionally been used by Indonesian fishermen, the ICJ observed that activities by private persons could not be seen as effectivités if they did not take place on the basis of official regulations or under governmental authority. 78 Thus, China and Vietnam have a huge burden to prove that the acts of their fishermen were not merely private acts.

In the Legal Status of Eastern Greenland Case, the PCIJ made a statement that if claims are made to sovereignty over areas in thinly populated areas or unsettled countries, it would be satisfied with very little in the way of the actual exercise of sovereign rights, provided that the other State could not make out a superior claim.79 In the Indonesia $v$. Malaysia Case, the ICJ accepted the statement while deciding the sovereignty of the two tiny islands, namely, the Ligitan and Sipatan. In the case of the Spratly Islands, most of islands possess the same characteristics as the Ligitan and Sipadan, very small, uninhabited or not permanently inhabited at least until recently, China may use the following acts to support its authority over the Islands:

1. In 1946, the ROC sent to and garrisoned its troops on the Islands;

2. In 1955, the ROC was requested by the ICAO to establish meteorological observations throughout the Spratly Islands;

3. In 1956, the ROC resent its troops to the Islands and continued to retain troops on the Taiping Island (Itu Aba Island);

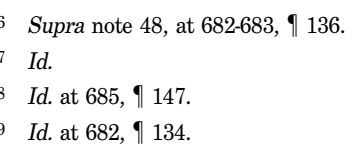


4. In 1958, the PRC, as successor of the ROC, promulgated a degree in the name of the Declaration of Territorial Sea of the PRC;

5. In 1988, the PRC sent its troops to some of the Islands and built a ferry and a helicopter airport there. It also built a Maritime Observation Station on one of the Islands based on the UNESCO plan and support; and

6. In 1992, the PRC passed the Law of the PRC on the Territorial Sea and Contiguous Zone, which includes the Spratly Islands as China's territory. 80

The maps issued by other States also support China's authority over the Spratly Islands. In addition, Vietnam 'officially' admitted that both the Paracel Islands and Spratly Islands are China's territory. 81 (Figure 1)

Figure 1: The note that was sent by Premier Pham Van Dong of the Vietnamese Government to Premier Zhou Enlai of the PRC on September 14, 1958

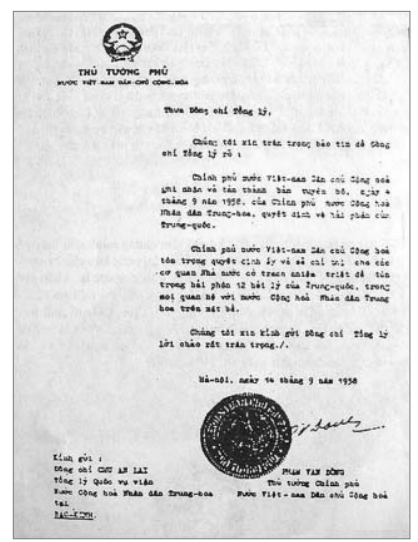

Source: Situation over Nansha Islands, available at http://www.kaixin001.com/repaste/7718958_ 5073058535.html (last visited on Mar. 21, 2012).

81 Vice Foreign Minister Dung Van Khiem of the Democratic Republic of Vietnam received Mr. Li Zhimin, charge d' affaires ad interim of the Chinese Embassy in Vietnam and told him that: "According to Vietnamese data, the Xisha and Nansha Islands are historically part of Chinese territory." Mr. Le Doc, Acting Director of the Asian Department of the Vietnamese Foreign Ministry, who was present then, added that: "Judging from history, these islands were already part of China at the time of the Sung Dynasty." Nhan Dan of Vietnam reported in great detail on September 6, 1958 the Chinese Government's Declaration of September 4, 1958 that the breadth of the territorial sea of the People's Republic of China should be 12 nautical miles and that this provision should apply to all territories of the People's Republic of China, including all islands on the South China Sea. On September 14 of the same year, Premier Pham Van Dong of the Vietnamese Government solemnly stated in his note to Premier Zhou Enlai that: "The Vietnamese 
Thus, the Chinese claims become stronger on the basis of estoppel. The ICJ made a statement in the Preah Vihear Temple Case expressly recognizing estoppel as a means of restricting a State from altering its position or denying the truth of a prior statement. 82 Although Vietnam may argue that its declarations, recognizing the Spratly Islands as China's territory, are not binding because they arose from vitiated consent, it is very difficult for Vietnam to prove such a vitiated consent. 83

The Vietnamese claim becomes quite weak on the basis of its first discovery of the Spratly Islands while confronted with a huge historical record provided by China. Actually, the historical records that Vietnam has given as evidence of its first discovery only mentioned some small islands along its coast, which are not the Spratly islands at all. 84

Robert Jennings defined 'occupation' as the "appropriation by a State of a territory which is not at the time subject to the sovereignty of any State." 85 Under international law, China can rely on discovery, treaty, effective control and estoppel to win its title to the Spratly Islands.

\section{Peaceful Resolution of the Disputes on the South China Sea: A Proposal}

The settlement of the Spratly Islands sovereignty disputes is envisioned as a real Gordian knot in consideration of their complexity, which has inclined not only China but also the other parties to the dispute to use negotiations to settle their disputes. In 1976, in order to tackle the disputes that may disturb regional peace and harmony, the members of the ASEAN worked out the Treaty of Amity and Cooperation ("TAC") which provides that the members "shall at all times settle disputes among themselves through friendly negotiations." 86 In November 2002, the PRC signed a Code of Conduct

government approves of the declaration ... and will give all state organs concerted directives aimed at ensuring strict respect of Chinese territorial water fixed at 12 nautical miles in all relations with China at Sea." See the copy of the original note at Figure 1. See Ministry of Foreign Affairs of the People's Republic of China, supra note 17.

82 Temple of Preah Vihear Case (Cambodia v. Thai.), 1962 I.C.J. 6 (June 15). For details on the Preah Vihear Case, see Bora Touch, Who Owns the Preah Vihear Temple?: A Cambodian Position, 2 J. EAst AsIA \& INT' L L. 205-227 (2009); Monticha Pakdeekong, Who Owns the Preah Vihear Temple? A Thai Position, 2 J. EAST AsIA \& INT'L L. 229-237 (2009).

83 Harry Roque Jr., China's Claim to the Spratlys Islands, 15 J. EnERgy \& NAT. ResourCes L. 204-205 (1997).

84 Shen, supra note 8 , at 57-58.

85 RoBert JENNINGS, THE ACQUISITION OF TERRITORY IN INTERNATIONAL LAW 20 (1963).

86 Article 13 of the TAC provides: "In case disputes on matters directly affecting them should arise, especially disputes 
in the South China Sea with the ASEAN confirming the principle of friendly negotiations contained in the 1992 Declaration. Then, in 2003, China acceded to the TAC, which is an impressive testament to the determination of its 'good neighbour' policy and inclination to peace.

Nevertheless, we must bear in mind that negotiations encouraged by the TAC, 87 from the Chinese viewpoint, refer to a method to manage the disputes rather than that to resolve territorial disputes. The former Chinese Vice Foreign Minister Yi Wang assessed that the 2002 Code of Conduct in the South China Sea would not resolve territorial conflicts, but allow peace to reign and help claimant countries focus on economic development. 88 Without the active participation of the PRC, no solution to the Spratly Islands problem will be permanent on practical as well as political level.89 China's proposal of joint development with sovereignty on the shelf is based on the premise that negotiations are not so effective for resolving the sovereignty disputes of the Spratly Islands. In other words, joint development around the Spratly Islands is negotiable between the parties concerned.90

It remains doubtful that China and Vietnam would resolve their territorial disputes in the South China Sea in the near future. But they are still trying to negotiate with each other for a joint development area around the disputed islands. In March 2005, the State-owned oil companies of China, Vietnam and the Philippines signed an agreement with regard to the conducting of oil pre-exploration surveys in the Spratly Islands. 91 These initiatives are indicative of the political will of the States concerned to develop the disputed area jointly.

China and Vietnam need to push themselves further by starting bilateral negotiations to define their joint development area during the process of their management of the disputes. This so-called 'economy first' method can be found in several other cases. For example, when the United Kingdom and France took the

likely to disturb regional peace and harmony, they shall refrain from the threat or use of force and shall at all times settle such disputes among themselves through friendly negotiations." See the text of the TAC, available at http://www.aseansec.org/1217.htm (last visited on Jan. 31, 2012).

87 Article 17 of the TAC provides: "The High Contracting Parties which are parties to a dispute should be encouraged to take initiatives to solve it by friendly negotiations before resorting to the other procedures provided for in the Charter of the United Nations." See Shen, supra note 8.

88 Hong Thao Nguyen, The 2002 Declaration on the Conduct of Parties in the South China Sea: Note, 34 OCEAN Dev. \& INT' L L. 279 (2003).

89 Biran Murphy, Dangerous Ground: The Spratly Islands and International Law, 1 OCEAN \& COASTAL L. J. 210 (19941995).

90 Joint Development Key to Resolving South China Sea Dispute, People's Daily OnLine, July 11, 2012, available at http://english.peopledaily.com.cn/90001/90780/91343/7437589.html (last visited on Mar. 21, 2012).

91 China, Vietnam agree on Exploitation in S. China Sea, XIN HuA NewS, July 20, 2005, available at http://in.chinaembassy.org/eng/zgbd/t204299.htm (last visited on Jan. 31, 2012). 
Minquiers and Ecrehos Case ${ }^{92}$ to the ICJ, they had already resolved the issue of fishing rights around the islands in a separate agreement.93 During the Sino-Russian border settlement, both also signed the agreement on joint economic use of several disputed islands of border rivers and of waters around them. ${ }^{94}$

Obviously, the purpose of signing joint development agreements is to guarantee the disputing parties' right to benefit from the natural resources in the disputed area. The successful arrangement of economic interests around the Spratly Islands would help China and Vietnam to build up their confidence in avoiding conflicts.

\section{Conclusion}

The disputes in the South China Sea concern both issues of territorial acquisition and maritime delimitation. Without resolving the territorial disputes over the islands in the South China Sea, the discussion of the maritime delimitation in the area would be groundless. In such a case, it would be necessary for China and Vietnam to assess their territorial claims based on international law, particularly the case law of the ICJ, before they start to negotiate on how to jointly develop the disputed areas. Although it is still unforeseeable for the two States to submit their territorial disputes to the ICJ in the near future, international law always serves as the third party. Further, the relevant decisions made by the ICJ may help them to review their justifications. Legally speaking, China claims its rights over the islands in the Spratly archipelago based on discovery and occupation, treaty and estoppel, while Vietnam claims the rights based on discovery and occupation only. The case concerning Sovereignty over Pulau Litigan and Pulau Sipadan (Indonesia v. Malaysia) before the ICJ implies that China would win its title to the Spratly Islands based on discovery, treaty, effective control and estoppel.

No one denies that the disputes in the South China Sea are very complex and provocative. The history of military clashes in the area, the involvement of six parties in the disputes, and many political variables related to the parties are challenging the conventional dispute-resolving mechanisms. 95 Although the Chinese claims to the

92 Minquiers and Ecrehos Case, 1953 I.C.J. 47. (Nov. 17).

93 J. G. Merrills, International Boundary Disputes in Theory and in Practice: Precedents Established, in PEACEFUL Resolution of MaJor InTERnational Disputes 99 (Julie Dahlitz ed. 1999).

94 V. S. Kotliar, The Elements of A 'Model Negotiation' for the Settlement of Major Border Disputes between States, in Dahlitz, id. at 133 .

95 Christopher Joyner, The Spratly Islands Dispute in the South China Sea: Problems, Policies, and Prospects for Diplomatic Accommodation, in RAnJeEt Singh, Investigating Confidence-Building MEASURES IN THE Asia-Pacific REGION 93 (1999). 
234 Junwu Pan

Spratly Islands are stronger on the basis of international law, under the present circumstance, it is still in the interest of both China and Vietnam to manage their sovereignty dispute over the Spratly Islands by negotiating the joint development areas. The "economy first policy" would remain the core position of the management as well as the settlement of the disputes in the South China Sea. 